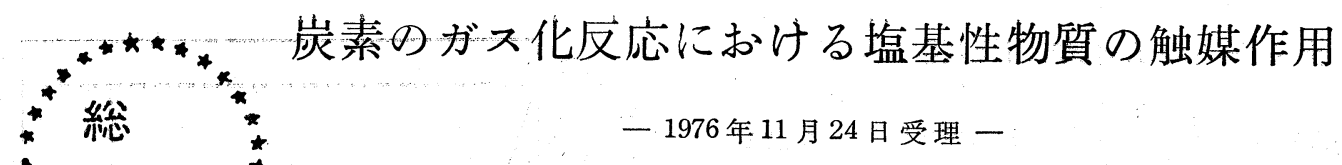

早 稲田大学* 森田義郎, 木村孝良

1. はじめに

近年のエネルギー危機以来，劣質然料である残油お よび石炭の有効利用が重要な問題となってきた。現代 では, この問題を解決するにあたって大量のエネルギ 一消費に伴なら大気, 水の污染などの環境対策をる考 慮したプロセスの開発が望まれている。これらの問題 の対応策として残油拉よび石炭のガス化があり，特に これらのガス化に対し促進作用と脱硫作用を同時に有 する炭酸ナトリムム拉よび石灰, ドロマイトなぞの塩 基性物質を用いたプロセスが研究開発されて, 注目を 集めている。

工業的なプロセスなどに関する事柄は最近の総

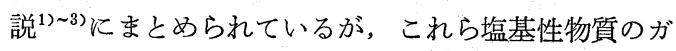
ス化に対する触媒作用については他の分野の触媒に比 ベ不明な点が多く重質油のガス化でわずかに推論 ${ }^{455}$ が見られるのみである。

最近, 残油の高温水蒸気改質反応がドロマイトや $\beta^{\prime \prime}$-アルミナ $\left(\mathrm{K}_{2} \mathrm{O} \cdot 5 \mathrm{Al}_{2} \mathrm{O}_{3}\right)$ 触媒の表面に析出する 炭素を反応中間体として進行することを著者らは見い

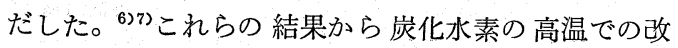
質反応に対する塩基性物質の触媒作用の研究に和いて も炭素のガス化に対する触媒作用が興味深いものとな った。そこで本総説では長年にわたり研究対象となっ ている炭素のガス化反応汶する塩基性物質の触媒作 用について概観し, 残油の高温改質反応飞対する塩基 性物質の触媒作用を研究するにあたっての問題点を明 らかにして見たい。

\section{2. 無触媒での炭素のガス化}

炭素のガス化は次の基本式で示されるような, 炭素 とガス化剤（酸素, 二酸化炭素, 水蒸気）との反応を 意味する。

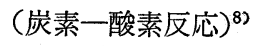

$$
\begin{aligned}
& \mathrm{C}+\mathrm{O}_{2} \rightleftarrows \mathrm{CO}_{2} \quad \Delta \mathrm{H}=-94.03 \mathrm{kcal} / \mathrm{mol} \\
& \text { （完全燃焼反応） } \\
& \mathrm{C}+1 / 2 \mathrm{O}_{2} \rightleftarrows \mathrm{CO} \quad-26.62
\end{aligned}
$$$$
\text { （不完全燃焼反応） }
$$

\footnotetext{
*理工学部 東京都新宿区西大久保4-170
}

$$
\begin{aligned}
& \mathrm{CO}+1 / 2 \rightleftarrows \mathrm{CO}_{2} \quad-67.41 \\
& \text { (CO 酸化反応) } \\
& \text { (炭素-二酸化炭素反応 })^{8)} \\
& \mathrm{C}+\mathrm{CO}_{2} \rightleftarrows 2 \mathrm{CO} \quad \Delta \mathrm{H}=+40.79 \\
& \text { （発生炉ガス反応） } \\
& \text { (炭素-水蒸気反応 })^{8)} \\
& \mathrm{C}+\mathrm{H}_{2} \mathrm{O} \rightleftarrows \mathrm{CO}+\mathrm{H}_{2} \quad \Delta \mathrm{H}=+31.14 \\
& \text { （水性ガス反応） } \\
& \mathrm{CO}+\mathrm{H}_{2} \mathrm{O} \rightleftarrows \mathrm{CO}_{2}+\mathrm{H}_{2}-9.65 \\
& \text { (CO 転化反応) } \\
& \mathrm{C}+\mathrm{CO}_{2} \rightleftarrows 2 \mathrm{CO} \quad+40.79 \\
& \text { (発生炉ガス反応) } \\
& \mathrm{C}+\mathrm{H}_{2} \rightleftarrows \mathrm{CH}_{4} \quad-17.87 \\
& \text { （水添メタン化反応） }
\end{aligned}
$$

以上の式からわかるように炭素と酸素の反応では一 酸化炭素と二酸化炭素が, 炭素々二酸化炭素の反応で は一酸化炭素が，炭素々水蒸気の反応では水素々一酸 化炭素, 二酸化炭素, メタンがそれぞれ生成物として 得られる。これらの反応の平衡論的な解説は森田 ${ }^{1)}$ 山村と石栄 ${ }^{3)}$ の総説に記述されているのでここでは省 略する。ただし, 炭素一水蒸気反応における(7).式の炭 素の水添メタン化反応は平衡定数も反応速度も非常に 小さく, 通常の常圧, 高温でのガス化条件では進行し がたいので生成物として一酸化炭素, 二酸化炭素を生 成する過程に対する触媒作用についてのみ言及する。

これら炭素のガス化は, 高温では無触媒でも進行す るが炭素表面自体が連続的淿消費され变化する不均一 表面反応であるため複雑で炭素のガス化自体十分な理 解がなされていない。そこで触媒を含む炭素のガス化 について記述する前に無触媒での炭素のガス化につい て簡単にふれよう。

無触媒での炭素のガス化では表 1 亿示されるように 各ガス化剈との反応に护ける炭素の 反応性 の序列は $\mathrm{C}-\mathrm{O}_{2}>\mathrm{C}-\mathrm{H}_{2} \mathrm{O}>\mathrm{C}-\mathrm{CO}_{2}$ であり, 活性化エネルギ 一も炭素の反応性の序列と対応している ${ }^{8)}$ 。また反応 次数は反応条件によって変化するが 0 次から 1 次の間 の值を取ることが示されている8)。反応速度論的解析 
表 1 種々のガス化剤による炭素のガス化

\begin{tabular}{lclc}
\hline 反応 & $\begin{array}{c}\text { 活 } \\
\text { 性 } \\
\mathrm{kcal} / \mathrm{mol}\end{array}$ & 相対速度* & 反応次数 \\
\hline $\mathrm{C}-\mathrm{O}_{2}$ & $50 \sim 58$ & $1 \times 10^{5}$ & 1 \\
$\mathrm{C}-\mathrm{CO}_{2}$ & 86 & 1 & $0 \sim 1$ \\
$\mathrm{C}-\mathrm{H}_{2} \mathrm{O}$ & ca. 80 & 3 & $0 \sim 1$ \\
\hline
\end{tabular}

*反応温度 $800^{\circ} \mathrm{C}$, 分圧 $0.1 \mathrm{~atm}$ に掓けるガ ス-炭 素反応の相対速度

およびガス化剂などの吸着による研究からは，いずれ のガス化剤を用いた場合る, 反応中間体として炭素表 面に生成する表面酸化物を経由し一酸化炭素, 二酸化 炭素を生成することが明らかにされている。例えば水 蒸気をガス化剤とすると通常(8)式の速度式が報告され ている。

$$
r=\frac{k_{1} P_{\mathrm{H}_{2} \mathrm{O}}}{1+k_{2} P_{\mathrm{H}_{2}}+k_{3} P_{\mathrm{H}_{2} \mathrm{O}}}
$$

ただし， $r$ は反応速度， $P_{H_{2}} \mathrm{O}, P_{H_{2}}$ はそれぞれ水 蒸気, 水素の分圧である。 $k_{1}, k_{2}, k_{3}$ は定数である。 この速度式から次のような反応機構が示されている。

$$
\begin{aligned}
2 \mathrm{C}_{f}+\mathrm{H}_{2} \mathrm{O}(\mathrm{g}) & \rightarrow \mathrm{C}(\mathrm{H})+\mathrm{C}(\mathrm{OH}) \\
\mathrm{C}(\mathrm{H})+\mathrm{C}(\mathrm{OH}) & \rightarrow \mathrm{C}\left(\mathrm{H}_{2}\right)+\mathrm{C}(\mathrm{O}) \\
\mathrm{C}(\mathrm{O}) & \rightarrow \mathrm{CO}(\mathrm{g}) \\
\mathrm{C}\left(\mathrm{H}_{2}\right) & \rightleftarrows \mathrm{C}_{f}+\mathrm{H}_{2}(\mathrm{~g})
\end{aligned}
$$

$\mathrm{C}_{\boldsymbol{f}}$ 注炭素表面で反応関与する炭素, $\mathrm{C}(\mathrm{O})$ は水 蒸気が炭素表面で解離され生成した表面酸化物であ る。ただしこの表面酸化物の構造などの知見は得られ ていない。

さらに反応状態で炭素表面に生成する表面酸化物の 量は炭素表面に存在する炭素の数％であることか ら，炭素とガス化剤が反応するサイトは炭素格子平面 のエッジに位置する炭素であると推論されている9”。 この推論はグラファイトー酸素反応の 電子顕微鏡測定 による研究結果から確かめられている ${ }^{10) 11) 。 ~}$

\section{3. 塩基性物質の触媒効果}

炭素のガス化に拉ける種々の無機化合物の添加効果 に関する初期の研究では Kröger（1939年）による総 説年があり，近年の研究については Walker らによる 総説 ${ }^{13)}$ がある。

これらの総説で検封されている無機化合物の中です アルカリ金属化合物などの塩基性物質は高い触媒活性 を有することが明らかにされている。例えば，Taylor そ Neville ${ }^{14)}$ は活性炭の水蒸気 拉よび二酸化炭素に よるガス化を反応温度 $490^{\circ} \mathrm{C}, 525^{\circ} \mathrm{C}, 570^{\circ} \mathrm{C} て ゙$ 行な い, 種々の無機化合物の添加効果を検討した結果, 炭

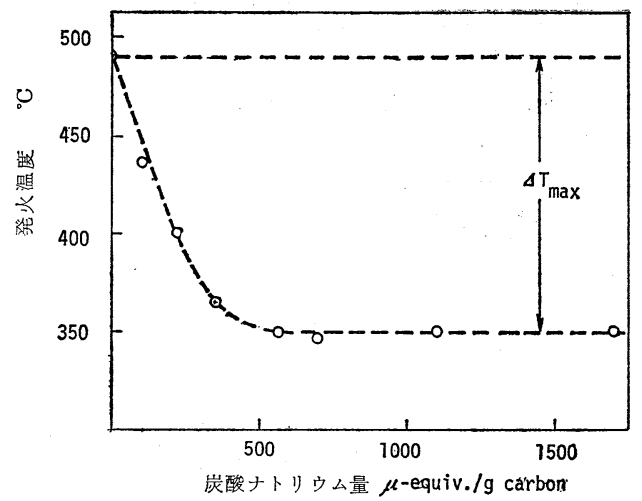

图 1 セルロースカーボンの発火温度におよぼす 炭酸ナトリウムの効果

酸ナトリウム, 炭酸カリウムがいずれの反応において も高い活性を示し，炭酸カルシウムは汪とんど活性の ないことを報告している。一方 Marson と Cobb' は反応温度 $1,000^{\circ} \mathrm{C}$ でのコークと水蒸気との反応を行 ない無触媒での水蒸気分解率 $61 \%$ 飞対し炭酸ナトリ ウムの $100 \%$, 酸化鉄の $95 \%$, 酸化カルシウムの $84 \%$ の值を得ている。炭素-酸素反応飞関しては Neumann と Von Ahlen ${ }^{16)}$ が $\mathrm{K}_{2} \mathrm{O}>\mathrm{CaO}>\mathrm{Fe}_{2} \mathrm{O}_{3}>$ 無触媒, $\mathrm{SiO}_{2}, \mathrm{Al}_{2} \mathrm{O}_{3}$ なる 活性序列を反応温度範囲 700 900 ${ }^{\circ} \mathrm{C}$ で得ている。また Harker ${ }^{17)}$ は連のア ルカリ金属炭酸塩特よびアルカリ土類金属炭酸塩を触 媒とし炭素と酸素との反応を行ない次の結果を得てい る。図 1 亿示されるように炭酸ナトリウムの添加量の 増加に伴ない発火温度は直線的に減少した後飽和值に

\begin{tabular}{|c|c|c|c|}
\hline \multirow{2}{*}{ 添加物 } & \multirow{2}{*}{$\begin{array}{c}\text { 発火温度底の最 } \\
\Delta \mathrm{T}_{\max }{ }^{\circ} \mathrm{C}\end{array}$} & \multicolumn{2}{|c|}{\begin{tabular}{l} 
金属原子のイオン化 \\
\multirow{*}{*}{. } \\
(I.P.) (ev)
\end{tabular}} \\
\hline & & First I.P. & Second I. P. \\
\hline $\mathrm{Li}_{2} \mathrm{CO}_{3}$ & 95 & 5.36 & - \\
\hline $\mathrm{Na}_{2} \mathrm{CO}_{3}$ & 120 & 5.12 & - \\
\hline $\mathrm{K}_{2} \mathrm{CO}_{3}$ & 150 & 4.32 & - \\
\hline $\mathrm{Rb}_{2} \mathrm{CO}_{3}$ & 160 & 4.16 & - \\
\hline $\mathrm{Cs}_{2} \mathrm{CO}_{3}$ & 200 & 3.87 & - \\
\hline $\mathrm{MgCO}_{3}$ & $<10$ & 7.61 & 14.96 \\
\hline $\mathrm{CaCO}_{3}$ & $<10$ & 6.09 & 11.82 \\
\hline $\mathrm{SrCO}_{3}$ & 20 & 5.67 & 10.98 \\
\hline $\mathrm{BaCO}_{3}$ & 40 & 5.19 & 9.95 \\
\hline
\end{tabular}
達する。この飽和值での発火温度と無触媒時の発火温 度との差 $\Delta \mathrm{T}_{\max }$ を触媒活性の表示とすると, 表 2 に

表 2 セルロースカーボンの発火温度に対する種 々の塩の効果 
表 3 表面 酸 化物 の 熱 分 解

[4 時間 $300^{\circ} \mathrm{C}$ で酸化したポリジビニルベンゼンカーボン $\left.\left(650^{\circ} \mathrm{C}\right)\right]$

\begin{tabular}{|c|c|c|c|c|c|c|c|c|}
\hline & \multicolumn{2}{|c|}{$\begin{array}{l}\mathrm{CO}_{2} \text { 生成量 } \\
(\mu \mathrm{moles} / \mathrm{g})\end{array}$} & \multicolumn{2}{|c|}{$\begin{array}{l}\mathrm{CO} \text { 生成量 } \\
(\mu \mathrm{moles} / \mathrm{g})\end{array}$} & \multicolumn{2}{|c|}{$\begin{array}{c}\text { 脱離した全酸素量 } \\
\left(10^{20} \text { atoms } / \mathrm{g}\right)\end{array}$} & \multicolumn{2}{|c|}{$\begin{array}{c}\text { 不対電子濃度 } \\
\left(10^{19} / \mathrm{g}\right)\end{array}$} \\
\hline 試 料 & \multicolumn{2}{|c|}{$\mathrm{NaOH}$ 添加 } & \multicolumn{2}{|c|}{$\mathrm{NaOH}$ 添加 } & \multicolumn{2}{|c|}{$\mathrm{NaOH}$ 添加 } & \multicolumn{2}{|c|}{$\mathrm{NaOH}$ 添加 } \\
\hline 酸化していない炭素 & - & - & - & - & - & - & 15.1 & - \\
\hline 酸化した炭素 & - & - & - & - & - & - & 3.9 & 3.8 \\
\hline 再加熱温度 $350^{\circ} \mathrm{C}$ & 210 & 1060 & 90 & 60 & 3.1 & 13.2 & 4.3 & 4.9 \\
\hline 400 & 430 & 1490 & 160 & 120 & 6.2 & 18.5 & 5.0 & 6.0 \\
\hline 450 & 770 & 1990 & 380 & 150 & 11.5 & 24.7 & 6.0 & 7.4 \\
\hline 500 & 1200 & 2480 & 820 & 330 & 19.3 & 31.8 & 7.6 & 9.2 \\
\hline 550 & 1520 & 3160 & 1420 & 890 & 26.7 & 43.3 & 9.5 & 12.9 \\
\hline 600 & 1770 & - & 1940 & - & 32.8 & - & 11.3 & - \\
\hline 650 & 2010 & - & 2980 & - & 42.1 & - & 14.9 & - \\
\hline
\end{tabular}

示されるよう飞 $\mathrm{Cs}>\mathrm{Rb}>\mathrm{K}>\mathrm{Na}>\mathrm{Li}$ 物よび $\mathrm{Ba}>$ $\mathrm{Sr}>\mathrm{Ca}>\mathrm{Mg}$ といら活性序列が得られ，これらの活 性序列がそれぞれの金属のイオン化ポテンシャルの減 少する序列と対応している。一方 Mckee と Chatle$\mathrm{rji}^{18)}$ とよればグラファイトー酸素反応でアルカリ金属 炭酸塩の活性序列は $\mathrm{Rb}, \mathrm{Cs}, \mathrm{Li}>\mathrm{K}>\mathrm{Na}$ である。 彼らはそれぞれのアルカリ金属炭酸塩を用いたとき， 発火温度が各アルカリ金属過酸化物の融点と対応する ことから触媒作用を論じ，序列の妥当性を確かめて いる。工業的なベンチスケールの研究に扮いても Hoynes $ら^{199}$ が反応温度 $850^{\circ} \mathrm{C}$, 圧力 $21 \mathrm{~kg} / \mathrm{cm}^{2}$ の条 件で石炭一水蒸気反応に対しアルカリ 金属化合物际よ び酸化鉄, 酸化カルシウム, 酸化マグネシウム, 酸化 亜鉛が有効な触媒であることを報告している。

\section{4. 塩基性物質の触媒作用}

上述した他にも，工業的なプロセスとして有名な炭 酸ナトリウムを用いる Kellogg 社の溶融塩法なども ありアルカリ金属化合物，アルカリ土類金属化合物は 炭素のガス化に活性な触媒であることがわかる。しか し炭素のガス化に対するアルカリ土類金属化合物の触 媒作用機構に関する研究はいまのところほとんど報告 されて抢らず，ここでは主としてアルカリ金属炭酸塩 を触媒として用いたこれまでの研究について, 反応を 炭素-酸素反応と炭素-二酸化炭素, 炭素-水蒸気 反応 の 2 つ分けて記述する。

\section{1 炭素-酸素反応}

Harker ${ }^{17}$ は図 1, 表 2 で示されるアルカリ金属炭酸 塩のセルロースカーボンの酸化に対する触媒効果を次 のように説明している。炭素表面に表面酸化物を 400 〜 500 C で生成させ，その分解反応を行なった実験で
アルカリが分解の開始温度を低下させる効果を示した ことから，アルカリの触媒作用は反応を阻害している 表面酸化物の安定性を減少させるものであると推測し ている。そして ESR による炭素の 不対電子濃度の 測定で, アルカリを含まない炭素の 不対電子濃度が $300^{\circ} \mathrm{C}, 30$ 分の酸化によって $10.4 \times 10^{19}$ 自由スピン数 $/ \mathrm{g}$ より $10^{18}$ 自由スピン数/g 以下へと著しく減少し, この酸化された炭素に水酸化ナトリウムを添加した後 $200^{\circ} \mathrm{C}$ で排気すると表面酸化物の脱離に起因すると思 われる不対電子の初期値近く $\left(6.9 \times 10^{19}\right.$ 自由スピン /g）へもどることから妥当としている。また Harkar は表 3 に示されるように炭素の不対電子濃度が酸化に より減少すること, 各再加熱濃度での水酸化ナトリウ

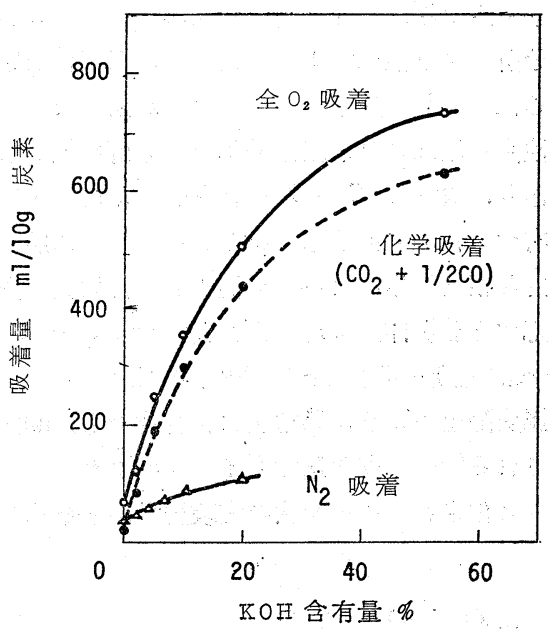

図 2 炭素表面酸化物の生成と分解および窒素吸 着におよぼすアルカリ含有量の効果 


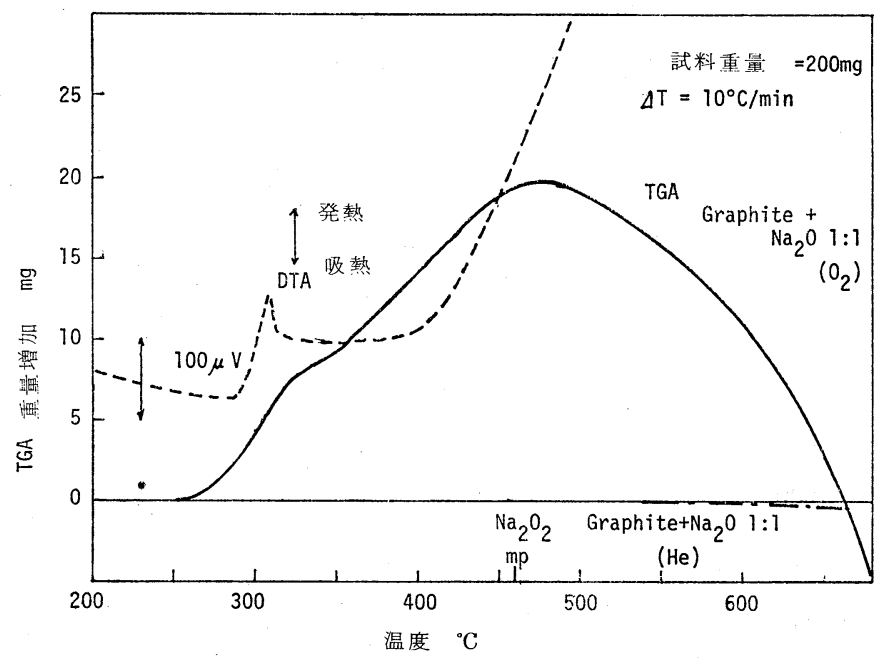

図 3 He および $\mathrm{O}_{2}$ 気流中での $1: 1$ グラファイト- $\mathrm{Na}_{2} \mathrm{O}$ 混合物に対する TG-DTA 加熱曲線 気体の流量 $=4.00 \mathrm{~m} l / \mathrm{min}$

ム添加による脱離酸素量の増加と脱離後の炭素の不 対電子濃度の増加とが対応することから確かめてい $ð^{20)}$ 。

しかし彼らは測定した不対電子が実際, 酸素によっ て，消失したのか，他の酸素原子に局在化した不対電 子などに変化したかは不明であるとして拉り，表 3 か らもわかるよらに不対電子一つに対応する表面酸素原 子数は約 50 に達することから, 実際の 炭素-酸素反 応にこの不対電子サイトがどれだけ関連性があるのふ は疑問の余地が残る。この炭素の表面酸化物の分解に 対するアルカリの効果を佐藤と赤松 ${ }^{211}$ は次のように説 明している。図 2 に示されるように炭素に加えた水酸 化カリウム量の増加に伴ない吸着酸素量掞よび表面酸 化物の分解により生成する一酸化炭素, 二酸化炭素の 量が増した。これは炭素上のアルカリが酸素吸着に対 する活性点を増加させ, 表面酸化物の分解を促進した ためであり, 炭素の $\mathrm{C}-\mathrm{C}$ 結合を弱める作用をアル カリが有するためと推論している。このように触媒と の電子的な相互作用によって活性化された炭素と酸素 とが反応する触媒作用に対し, 最近 Mckee と Chatterji ${ }^{18)}$ は熱重量一示差熱同時分析装置を用い，アル カリ金属炭酸塩のような典型金属化合物でも，(9)式(10) 式で示される触媒の酸化還元サイクルによりグラファ イトがガス化されることを次の実験結果から結論して いる。

$$
\begin{aligned}
& \mathrm{M}_{2} \mathrm{O}+\frac{n}{2} \mathrm{O}_{2} \rightleftarrows \mathrm{M}_{2} \mathrm{O}_{1+n} \\
& \mathrm{M}_{2} \mathrm{O}_{1+n}+\mathrm{nC} \rightleftarrows \mathrm{M}_{2} \mathrm{O}+\mathrm{nCO}
\end{aligned}
$$

\section{( $\mathrm{M}$ : アルカリ金属)}

一連のアルカリ金属炭酸塩を触媒とするとグラファイ 卜を酸素との反応開始温度がそれぞれアルカリ金属過 酸化物の融点に近く, 図 3 に示されるように $\mathrm{Na}_{2} \mathrm{O}$ グラファイト $-\mathrm{O}_{2}$ 系でも $\mathrm{Na}_{2} \mathrm{O}_{2}$ の融点付近からガ ス化に伴なう重量減少が起こり，低温側での重量増加 は(11)式で消費される酸素量にほぼ対応していることか ら上記した推論の裹づけとしている。

$$
\mathrm{Na}_{2} \mathrm{O}_{2}+1 / 2 \mathrm{O}_{2} \rightarrow \mathrm{Na}_{2} \mathrm{O}_{2}
$$

さらにこのアルカリ金属酸化物が $\mathrm{Na}_{2} \mathrm{CO}_{3}-$ グラファ イト $-\mathrm{O}_{2}$ 系からは平衡論的に生成しらることを示 し, 実際 $900^{\circ} \mathrm{C}$ では 表 4 に示されるように $\mathrm{Na}_{2} \mathrm{CO}_{3}$ ーグラファイトー $\mathrm{O}_{2}$ 系の方が $\mathrm{Na}_{2} \mathrm{CO}_{3}-\mathrm{O}_{2}$ 系より $\mathrm{Na}_{2}$ $\mathrm{O}$ の生成が多かったことより(10)式を確かめている。 また $600^{\circ} \mathrm{C}$ の温度での炭素表面の電子顕微鏡による 観察から,グラファイトの基底面に液状の過酸化物相 の生成に伴ない触媒によるチャネリングが見られたこ とからも(9), (10)式により触媒とグラファイトの接触面 でガス化反応が進行することを結論している。

\section{2 炭素-二酸化炭素および炭素-水蒸気反応}

初期の研究に抽いてはFox と White ${ }^{22)}$ はグラフ アイトー二酸化炭素反応における炭酸ナトリウムの触 媒作用の検討から， $1,000^{\circ} \mathrm{C}$ では(12)式が起こることを 実験的に確かめ, 次の(12) (14)式のサイクルでガス化が 進行する機構を提案している。

$$
\begin{array}{ll}
\mathrm{Na}_{2} \mathrm{CO}_{3}+2 \mathrm{C} \rightleftarrows 2 \mathrm{Na}+3 \mathrm{CO} & \text { (12) } \\
\mathrm{CO}_{2}+2 \mathrm{Na} \rightleftarrows \mathrm{Na}_{2} \mathrm{O}+\mathrm{CO} & \text { (13) } \\
\mathrm{Na}_{2} \mathrm{O}+\mathrm{CO}_{2} \rightleftarrows \mathrm{Na}_{2} \mathrm{CO}_{3} & \text { (14) }
\end{array}
$$


表 4 アルカリ金属酸塩からアルカリ金属酸化物の生成

\begin{tabular}{|c|c|c|c|}
\hline $\begin{array}{l}\text { 宸酸塩 } \\
\mathrm{M}_{2} \mathrm{CO}_{3}\end{array}$ & $\begin{array}{l}\mathrm{M}_{2} \mathrm{CO}_{3} \text { 中に含まれる } \\
\mathrm{M}_{2} \mathrm{O} \text { 濃度 }\end{array}$ & $\begin{array}{l}90{ }^{\circ} \mathrm{C} 4 \text { 時間 } \mathrm{O}_{2} \text { 中で } \\
\mathrm{M}_{2} \mathrm{CO}_{3} \text { 加熱後の } \\
\mathrm{M}_{2} \mathrm{O} \text { 濃度 }\end{array}$ & $\begin{array}{l}900^{\circ} \mathrm{C} 4 \text { 時間 } \mathrm{O}_{2} \text { 中で } \\
\mathrm{M}_{2} \mathrm{CO}_{3}+ク ゙ ラ フ ィ イ \\
\text { を加熱後の } \mathrm{M}_{2} \mathrm{O} \text { 濃度 }\end{array}$ \\
\hline $\mathrm{Li}$ & $<0.2 \mathrm{wt} \%$ & $2.1 \mathrm{wt} \%$ & $4.6 \mathrm{wt} \%$ \\
\hline $\mathrm{Na}$ & $<0.2$ & 0.2 & 1.1 \\
\hline $\mathrm{K}$ & $<0.2$ & 0.6 & 7.6 \\
\hline $\mathrm{Rb}$ & $<0.2$ & 1.6 & 6.6 \\
\hline $\mathrm{CS}$ & $<0.2$ & 3.2 & 7.7 \\
\hline
\end{tabular}

近年 Mckee とChatterji ${ }^{18)}$ はグラファイトと二酸 化炭素の反応に対する一連のアルカリ金属炭酸塩の効 果を熱重量分析装置を用いて検討した。その結果図 4 に示されるように各炭酸塩の活性序列 $\mathrm{Li}>\mathrm{Cs}>\mathrm{Rb}>$ $\mathrm{K}>\mathrm{Na}$ には一定の規則性は見られないが，ガス化に は $700^{\circ} \mathrm{C}$ 以上の温度を必要とし, 各炭酸塩の融点付近 からガス化による重量減少が著しくなること，さらに アルカリ金属の昇華が観察されたことなどから Fox とWhite が提案した(12) (14)式で反応は進行するとし ている。そして彼らはこの機構について次のような知 見を得ている。すなわちアルカリ金属炭酸塩ーグラフ アイト系を $\mathrm{He}$ 気流中, $\mathrm{CO}_{2}$ 気流中でそれぞれ高温 に加熱すると $\mathrm{He}$ 気流中では, $\mathrm{CO}_{2}$ 気流中よりも重 量が著しく減少することから $\mathrm{CO}_{2}$ 気流中ではアルカ リ金属の蒸発が抑兄られるものと解釈し(13)，(14)式の反 応サイクルの裏づけとしてている。

一方 Taylor と Nevill144はアルカリ金属炭酸塩を 触媒として活性炭の水蒸気拈よび二酸化炭素によるガ ス化を行なった。その結果, 反応温度範囲 $450^{\circ} \sim 570$

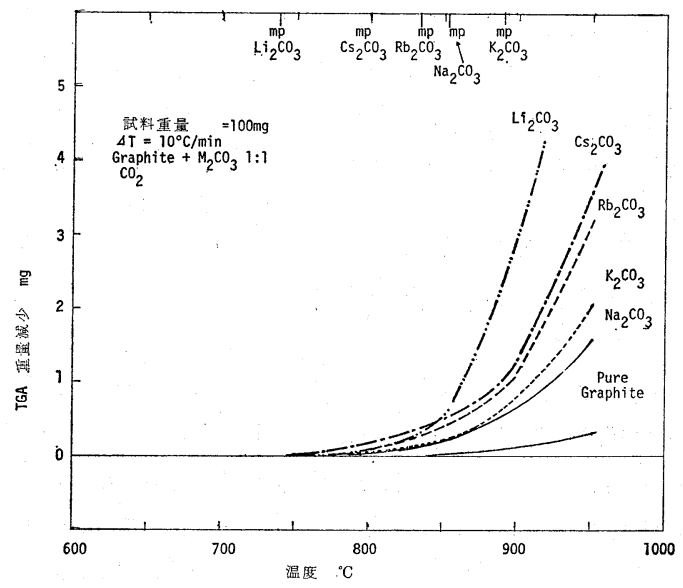

図 4 グラファイトの $\mathrm{CO}_{2}$ による|ガス化に対す るアルカリ金属炭酸塩の効果, 温度に対す る重量变化・気体流量 $=400 \mathrm{ml} / \mathrm{min}$
${ }^{\circ} \mathrm{C}$ では (15)式は実験的に起こらないことを知り，その 作用機構は次の(15)(16)式によるものでなく炭素表面に生 成する $\mathrm{CxOy}$ のような中間体の分解をアルカリが促 進すると推測している。

$$
\begin{aligned}
\mathrm{K}_{2} \mathrm{CO}_{3}+\mathrm{C} & \leftrightarrow \mathrm{K}_{2} \mathrm{O}+2 \mathrm{CO} \\
\mathrm{K}_{2} \mathrm{O}+ & \rightleftarrows \mathrm{K}_{2} \mathrm{CO}_{3}
\end{aligned}
$$

一方 Harker ${ }^{17)}$ はフッ酸拉よび塩酸で処理した梆子款 活性炭と二酸化炭素の反応を $700 \sim 900^{\circ} \mathrm{C}$ で検討し, $500^{\circ} \mathrm{C}$ での炭素と酸素との反応により表面酸化物を生 成させると炭素一酸化炭素反応が抑制されること， その表面酸化物の分解汇対しアルカリ化合物が促進効 果を有することなどから Taylor と Neville の推測 を裏づけている。Long と Sykes $\left.{ }^{23}\right)$ 不純物 $\left(\mathrm{Na}_{2} \mathrm{O}\right.$ $0.23 \%, \mathrm{~K}_{2} \mathrm{O} 0.84 \%, \mathrm{Fe}_{2} \mathrm{O}_{3} 0.21 \%, \mathrm{Al}_{2} \mathrm{O}_{3} 0.68 \%$, $\mathrm{SiO}_{2} 0.26 \%$ ) を含む活性炭 (未処理炭素) とその炭素 を塩酸とフッ酸で処理し不純物濃度を $0.04 \%$ に下げ た炭素（抽出された炭素）を用いて二酸化炭素と水蒸 気との反応を行なっている。この両炭素の反応につい て反応速度論的比較をした結果, 前に示した Taylor と Neville や Herker の報告しているような触媒と 炭素との相互作用による触媒作用を推測している。炭 素-二酸化炭素, 炭素-水蒸気反応子も未処理炭素の反 応性は抽出された炭素より良いが，反応進行に伴なう 生成物特よび酸素, 水素バランスから求めた表面吸着 種の量の変化には大きな差は観察されなかった。さら に炭素-二酸化炭素反応 では 表面吸着酸素量が未処理 炭素と抽出された炭素で同じであることから, 二酸化 炭素の吸着は触媒上ではなく炭素自身であると推測し ている。ガス化剤に対する吸着サイト数は炭素二二酸 化炭素反応では全炭素表面の 約 $0.5 \%$ であり，炭素水蒸気反応では両炭素々も全炭素表面の約 $2 \%$ であ ることから, 炭素格子平面のエッジに位置する炭素が 吸着サイトであると推測している。表 5 は彼らが流通 系の実験から反応の活性化エネルギーおよび吸着, 脱 着段階の活性化エネルギーを求めたものである。表 5 


\section{表 5 炭素のガス化の活性化エネルギーにおよぼ す触媒の効果}

\begin{tabular}{ccc}
\hline 反 応 & $\begin{array}{c}\text { 抽出された㟶素に } \\
\text { 凉ず活性化ネ } \\
\mathrm{kcal} / \mathrm{mol}\end{array}$ & $\begin{array}{c}\text { 未処理炭素に対する } \\
\text { 活性化エルギー } \\
\mathrm{kcal} / \mathrm{mol}\end{array}$ \\
\hline $\mathrm{C}+\mathrm{CO}_{2}$ & 74.0 & 68.0 \\
吸着段階 & 68.4 & 58.8 \\
脱着段階 & 66.0 & 38.0 \\
C $+\mathrm{H}_{2} \mathrm{O}$ & 83.0 & 55.0 \\
(脱着段階) & & \\
\hline
\end{tabular}

に示されるように触媒は活性化エネルギーを減少させ る働きを有し, 特に脱着段階の活性化エネルギーの減 少が著しい。以上の結果を説明するために次のよらな 仮説を提出している。

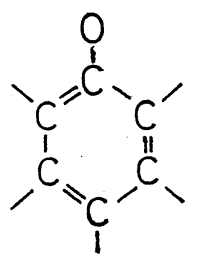

(a)<smiles>Cc1c(C)c(C)c(C)c(C)c1C</smiles>

(b)
酸素が炭素格子平面のエッジに位置する炭素に吸着 にした場合，上の $2 つ の ~ \pi$ 電子系が考光られ，触媒は (b)型の $\pi$ 電子分布を生成させ， C-C 結合の切断を 容易にし $\mathrm{C}$ 一0 結合を強めることにより一酸化炭素 の生成を有利にする。(b)型では $\mathrm{C}-\mathrm{C}$ 結合が(a)型に 比べ弱くなるので脱着過程の活性化エネルギーの減少 を脱明できる。 $\pi$ 電子の移動性のため触媒は炭素格子 の同一面に存在すればよく触媒が活性点に位置する必 要がない。アルカリの作用についてはアルカリが炭素 と共有結合性の結合をするため(b)型をとると彼らは説 明している。しかしこの仮説は, 構造(b)が電子受容体 々考兄られる遷移金属酸化物に対し説明されるもので あり, 強い電子供与体でアルカリの作用に対しては説 明されがたい欠点を有する。

以上述べてきたように炭素のガス化はいずれのガス 化剂を用いたときでも，触媒作用は Walker $ら^{13}$ が 分類した酸素移行機構か電子移行機構のいずれかで説 明されている。前者は Mckee とChatterji ${ }^{18)}$ の報告 に見られるように触媒がガス化剂を解離し生成した触 媒の酸素原子が炭素と反応寸るもので，いわゆる触 媒の酸化一還元サイクルによる機構である。後者は Harker ${ }^{17}$ や Long と Sykes ${ }^{23}$ らの結果に見られる
ので触媒と炭素が電子的に相互作用し炭素の電子状態 が変化することによりガス化剈と炭素との反応速度が 增大するものである。しかしどちらの機構でガス化が 進んでいるかという決定的な根拠はまだ報告されてい ないが，炭素-酸素反応に扔いて Mckee と Chatte$\mathrm{rji}^{18)}$ がアルカリ粒子によるグラファイト基底面でのチ ャネリングを観察した事実は触媒と炭素の境界面で反 応が進行することを証明したものであるら。彼らは炭 素-二酸化炭素反応でも $1,000^{\circ} \mathrm{C}$ までの電子顕微鏡に よる測定をアルカリ触媒とグラファイトの系で試みた がチャネリングなどの変化は観察されなかったと報告 している。したがってガス化剤が変わると反応機構も 異なる可能性もあると判断するには, 炭素-水蒸気反 応, 炭素二二酸化炭素反応汇関する報告が少なく, 今 後の研究に待らたい。

\section{5. 重質油ガス化への応用}

ここで残油のガス化に有効な酸化カルシウム， $\beta^{\prime \prime-}$ アルミナ触媒などの塩基性物質の触媒作用に対して, 炭素のガス化で得られた触媒の作用機構を応用してみ よう。これらの触媒に対しても同様に電子移行機構と 酸素移行機構が考えられる。前者の機構は著者らの $\beta^{\prime \prime}$ ーアルミナを用いた実験 ${ }^{24)}$ で, 触媒上に炭素が単純 に覆っていると仮定した場合, 単分子層以上の炭素が 析出していても炭素と水蒸気との反応性が変化しない ことから推測される。一方, Anderson 5 $5^{25)}$ は IR 測 定により $900^{\circ} \mathrm{C}$ の高温で排気した酸化マグネシウム表 面に水酸基が残存していることを報告している。また Rostrup-Nielsen ${ }^{26)}$ は担持ニッケル触媒を用いた炭化 水素の水蒸気改質反応で炭素析出におよ括よ担体の効 果を速度論的に研究している。その結果, 酸化マグネ シウムのような塩基性担体の炭素析出抑制効果を担体 之水蒸気との吸着が他の酸性担体よりも強いため水蒸 気が活性化され, ニッケル上の炭素質との反応が促進 されるためであるとしている。これら 2 つの結果は後 者の機構を示唆している。

したがって重質油や残油などのガス化に和ける酸化 カルシウム， $\beta^{\prime \prime}$ ーアルミナなどの塩基触媒の作用機構 を検討する際に，炭素のガス化に対する触媒作用の研 究を基礎に考光た場合, 触媒上飞単分子層以上の炭素 を析出させた後でも水蒸気などのガス化剤が触媒表面 飞吸着するか否か，また析出した炭素表面と触媒との 間飞電子的相互作用があるか否かなどが議論の対象と して考えられよう。

$$
\text { 文 献 }
$$

1) 森田, 燃協誌, 53, 239 (1974) 
2) 森田, 石油誌, 18, 725 (1975)

3) 山村, 石栄, 化学総説, No.12, p. 163 (1976)

4) 森田, 触媒工学講座 10 , 元素別, 触媒便覧p. 19 (1967)

5）森田, 重質油のガス化 (燃協編) p. 48 (1973)

6) 森田, 大沢, 深瀬, 山崎, 菊地, 石油誌, 投稿中

7) 木村, 中林, 久保田, 菊地, 森田, 第 7 回石油化 学討論会予稿集, p. 68 (1976)

8) P. L. Walker Jr, F.Rusinko Jr, L. G. Austin, Advan. Catalysis, XI, p. 133, Academic Press, New York, London (1959)

9) F. J. Long, K. W. Sykes, Proc. Roy. Soc. A, 193, 377 (1948)

10) A. F. B. Presland, J.A. Hedley, J. Nucl. Materials 10, 99 (1963)

11) J. M. Thomas, Carbon, 7, 359 (1969)

12) C. Kröger, Angew. Chem, 52, 129 (1939)

13) P. L. Walker, M. Shelef, R. A. Anderson, Chemistry and Physics of Carbon 4, p. 287 Edward Arnold, London (1968)

14) H. S. Taylor, H. A. Neville, J. Am. Chem. Soc., 43, 2055 (1921)

15) C. B. Marson, J.W. Cobb, Gas. J., 29, 882 (1926)
16) B. Neumann, A van Ahler, Breunstoff Chem., 15, 5 (1934)

17) H. Harker, Proc. 4 th. Conf. Carlon, p. 125 Pergamon Press, Oxford (1960)

18) D. W. Mckee, D. Chatterji, Carbon, 13, 381 (1975)

19) W. P. Haynes, S. J. Gasior, A. J. Forney, Preprints, Div. of Fuel Chemistry, ACS, 18 (2) 1 (1973)

20) H. Harker, C. Jackson, W. F. K. Wynne-Jones, Proc. Roy. Soc., 262, 328 (1961)

21) H. Sato, H.Akamatu, Fuel, 33, 195 (1954)

22) D. A. Fox, A. H. White, Ind. Eng. Chem., 23, 259 (1931)

23) F. J. Long, K. W. Sykes, J.Chim. Phys., 47, 361 (1950)

24) T. Kimura, N. Nakabayashi, M. Yumoto, E. Kikuchi, Y.Morita, Bull. Japan. Petrol.Inst, 投稿中

25) J. Anderson, R. F. Horlock, J. F. Oliver, Trans. Faraday. Soc., 61, 2754 (1965)

26) J. R. Rostrup-Nielsen, J. Catal., 33, 184 (1974)

\title{
Catalysis of Basic Materials for Gasification of Carbon
}

\author{
by Yoshiro Morira, Takayoshi Kimura \\ (Waseda University)
}

SYNOPSIS :-The efficent utilization of residual oil and coal has become a important problem since energy crisis. Gasification of residual oil and coal with basic catalysts such as sodium carbonate and calcium oxide has been attracted attention because of their promoting effect for the reaction and their ability of desulfurization. However, a fundamental understanding of the catalysis of basic materials for gasification has lagged for far behind its industrial applications.

This paper reviews catalysis of basic materials for reactions of carbon-oxygen containing gases (oxygen, carbon dioxide and steam). In this review, the mechanism of catalysis of alkali compounds was classified by oxygen-transfer mechanism and electron-transfer mechanism. Problems in the study for mechanism of catalysis of basic materials on gasification of residual oil were discussed on the basis of the mechanisms classified. 